\title{
SPECIATION OF CADMIUM, COPPER, LEAD AND ZINC IN THE WATERS OF RIVER MSIMBAZI DAR ES SALAAM, TANZANIA
}

\author{
OC Othman \\ Chemistry Department, University of Dar es Salaam, \\ P.O. Box 35061, Dar es Salaam, Tanzania
}

\begin{abstract}
The water of river Msimbazi and its attributaries are known to contain heavy metals originating from industry and the water is used for domestic and vegetable irrigation purposes. The present study describes chemical forms of some of the heavy metals found in the water. Water samples from different locations along river Msimbazi were analysed by Differential Pulse Anodic Stripping Voltammetry (DPASV) based on an operational scheme for the determination of the chemical forms of dissolved copper, lead, cadmium and zinc. Zinc $(82 \%)$, cadmium (73\%) and copper $(93 \%)$ were found to exist mainly as soluble metal ions while lead existed as moderately soluble ions $(<60 \%)$. On the average, $40 \%$ of the lead was found complexed to the filterable contents of the water as compared to only $6.6 \%$ of the copper, $17.5 \%$ of the zinc and $26.3 \%$ of the cadmium. Thus membrane filtration was able to remove quite a large amount of the pollutants.
\end{abstract}

The lability of the lead (52.6\%) in raw river water, was lower than that of zinc (61.6\%), copper (65.4\%) and cadmium $(61 \%)$. The lability of the lead $(38 \%)$ in filtered water, was also lower than that of zinc $(51.9 \%)$, copper $(63.7 \%)$ and cadmium (48.8\%). In raw river water, cadmium had the lowest ASV lability (42.0\%) as compared to zinc $(48.4 \%)$, copper $(50.7 \%)$ and lead $(47.4 \%)$ whereas in filtered water the ASV lability of lead (29.3\%) was the lowest; those of zinc (37.6\%), copper $(45.4 \%)$ and cadmium (40.8\%) were much higher. A high percent of the labile trace lead (27.8\%), cadmium (20\%) and zinc (15.7\%) and only $2.6 \%$ of the labile copper adhere to the filterable content of the water and thus may be filtered off. 


\section{INTRODUCTION}

Msimbazi river and its tributaries, which pass through the industrial and residential areas of Dar es Salaam, drains and receives treated and untreated discharges of various types. The waters from this river are used for domestic, agricultural and other uses. It has been reported that the river water contains heavy metals (Ak'habuhaya \& Lodnius 1988, Qamara \& Othman 1996).

The previous reports have given only the total concentrations of these metals but it is well known that the total concentration of a trace metal in a natural water system may not correlate well with its impact on the aquatic life (Davidson 1978, Honeyman \& Santschi 1988). Water with a high total metal concentration may in fact be less toxic than that with a lower concentration. It is the specific chemical form of a metal that determines its ecological significance and in particular their bio-availability (Florence \& Batley 1977, Figura \& McDuffie 1980). Low doses of toxic metals such as cadmium, lead and mercury taken over a long period eventually lead to cancerous levels that interfere with the action of enzymes and other biochemical processes in an organism. Ingested cadmium gets accumulated, particularly in the renal system, bones and liver and thus represents a lasting health hazard (Figura \& McDuffie 1980).

Several reports have discussed speciation of trace elements in natural waters and the methods of studying it using Stripping Voltammetry (SV) (Batley 1989, Florence 1982, Batley \& Florence 1976a, Othman 1986). The present study looked at chemical forms of the heavy metals cadmium, copper, lead and zinc in river Msimbazi waters during September to December 1998 using SV techniques.

\section{MATERIALS AND METHODS \\ Study area}

Samples of water were taken from river Msimbazi that runs through the city of Dar es Salaam (Fig. 1). The river is about $35 \mathrm{~km}$ long with an approximate catchment area of 300 square kilometres (Kondoro 1997). It has three tributaries namely Sinza, Ubungo and Luhanga rivers (See Fig. 1). These rivers flow through industrial, urban and agricultural areas of Dar es Salaam where they pickup heavy metals. Six sampling locations were identified: two on river Sinza, one on river Ubungo, one on river Luhanga and two on river Msimbazi (Fig. 1). 


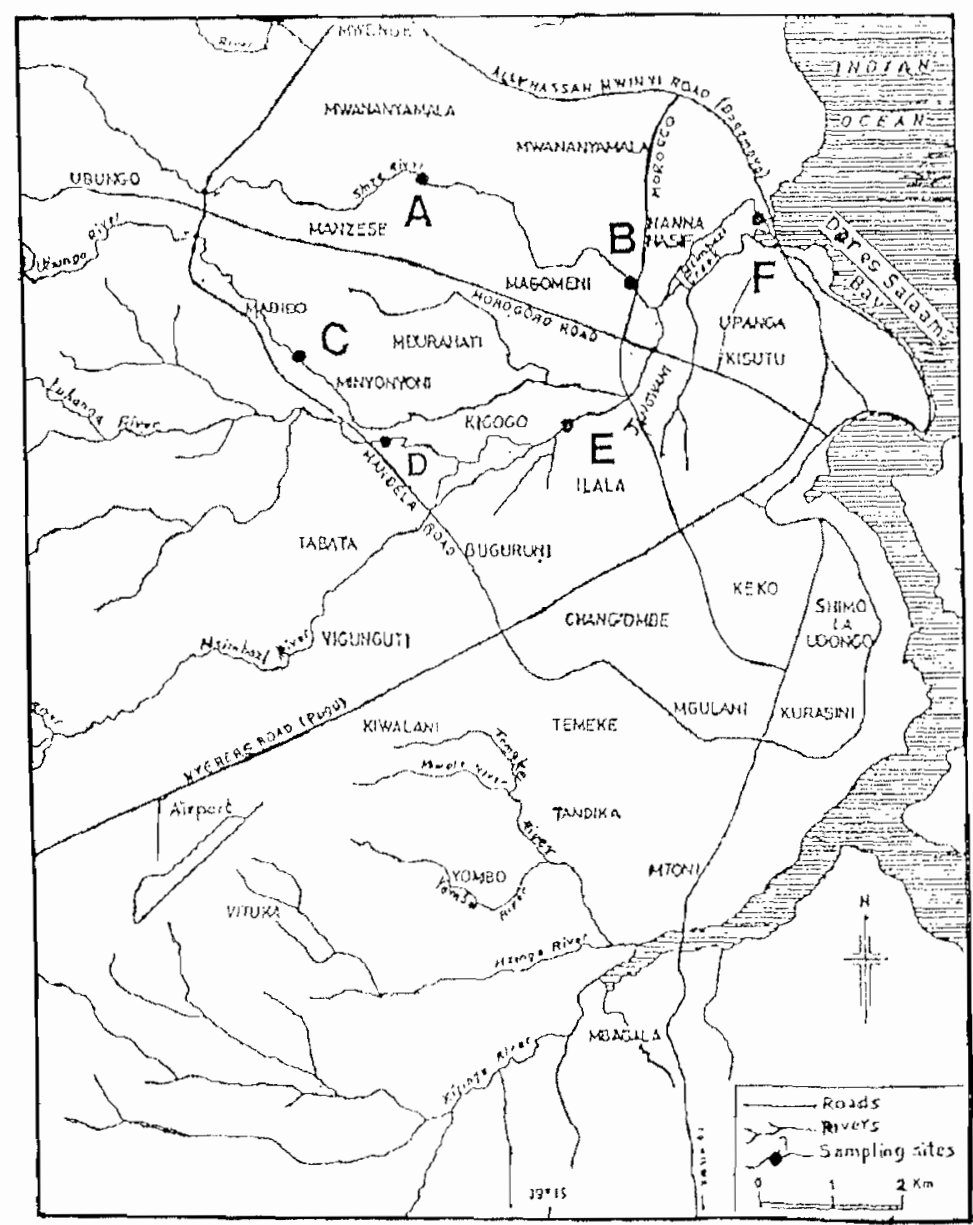

Fig. 1: Map of river Msimbazi and its tributaries showing the sampling locations A-F

\section{Collection and treatment of the water samples}

Water samples were collected as described elsewhere (Batley \& Florence 1976b, Brukland et al. 1979). At each site three samples were collected and stored. The first sample was acidified with nitric acid to $\mathrm{pH} 1.5$ to prevent and check metal ion loses to container walls (Othman 1986). The second water sample was stored at its natural $\mathrm{pH}$ to maintain species equilibrium conditions. The third sample was filtered through a $0.45 \mu \mathrm{m}$ membrane filter to remove any solid particles and any microbiological entities suspended in the water. The $\mathrm{pH}$ of the water was measured on site with a Beckman $\mathrm{pH}$ meter. The filtered and unfiltered samples as well as the filter residues were immediately subjected to laboratory analysis and when neecssary stored in a refrigerator at $6{ }^{\circ} \mathrm{C}$ before analysis. 


\section{Differential Pulse Anodic Stripping Voltammetry (DPASV) determinations}

Cadmium, copper, lead and zinc concentrations were obtained by DPASV determinations using the standard addition technique (Donat et al. 1994, Holak 1975, Florence 1972). A Princeton Applied Research Corporation (PARC) polarographic analyzer model $174 \mathrm{~A}$ connected to a model 303 static mercury drop electrode assembly (EG\&G 1978) was used.

To guard against contamination of the analyte in the voltammetric cell, each electrolyte container was used for only one determination per day. After each determination, this glass container was kept in $3 \mathrm{M}$ nitric acid until the following day. The electrodes were kept in distilled water for one hour between determinations and an ASV check on the distilled water was always made to ensure that it had leached out any trace metals picked up in the previous determinations. All solutions were deaerated with high purity nitrogen gas before analysis.

\section{Speciation procedures}

The flow chart for the speciation study is presented in Fig. 2 and is similar to that already reported elsewhere (Othman 1986). All water samples were analyzed in triplicate. All acids and other reagents were either of the super-pure analytical grade or of analytical grade that had been pre-cleaned electrolytically to ensure that they had negligible amounts of the heavy metals being studied. The determination procedures are described below.

\section{Determination of total metal content in the raw and filtered water samples}

To $25 \mathrm{~cm}^{3}$ of a water sample, $0.15 \mathrm{~cm}^{3}$ of concentrated nitric acid and 0.05 $\mathrm{cm}^{3}$ of perchloric acid were added (Othman 1986). The samples, in covered beakers on a hot plate set at about $140^{\circ} \mathrm{C}$, were boiled for 30 minutes. The samples were then left to cool to room temperature and diluted to $25.00 \mathrm{~cm}^{3}$ with deionized distilled water. A $10 \mathrm{~cm}^{3}$ aliquot was pipetted and used for the DPASV determination of total copper, lead and cadmium content. The determination of zinc at such low $\mathrm{pH}$ was complicated by the interference of the hydrogen evolution peak produced by the reduction of hydrogen ion (Florence \& Batley 1977). Relevant neutralization $(\mathrm{NaOH})$ of the aliquot to $\mathrm{pH} 4.7$ was made before the DPASV determination of zinc was performed (see also Othman 1986). 


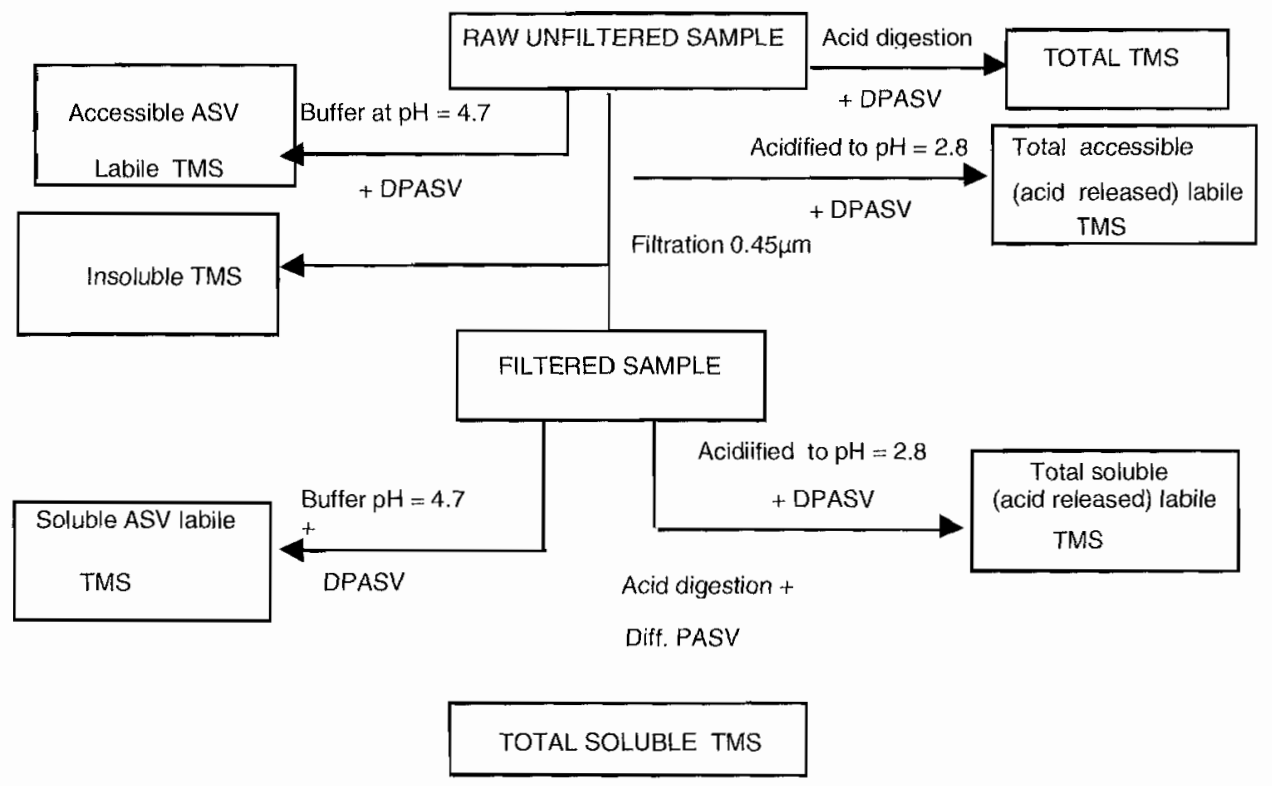

TMS - Trace Metal Species

ASV - Anodic Stripping Voltammetry

Fig. 2: Procedural layout for heavy metals speciation determination

The filtered water sample gave total soluble metal ion content while the unfiltered sample gave overall (total soluble and insoluble) metal ion content of the sample. Total metal ion contents gave a measure of the amount of both labile and non-labile species of these metals.

\section{Determination of amount of ASV labile and acid released labile species in the raw and filtered aqueous samples}

To known volumes of the unfiltered or filtered sample were added small amounts of concentrated perchloric acid to adjust the $\mathrm{pH}$ to 2.8 . The analytical blank value, which was almost negligible, was obtained by the DPASV scan of the acidified de-ionized distilled water. The metals in such acidified filtered and unfiltered samples were then determined by DPASV. This determination gave a measure of the ASV labile and acid-released labile species in the aqueous samples. 


\section{Determination of labile trace metal species in the water samples}

Direct DPASV determinations of the unfiltered and filtered water samples were made after addition of $0.15 \mathrm{~cm}^{3}$ of a $1 \mathrm{M}$ acetate buffer $(\mathrm{pH}=4.7)$ to $25 \mathrm{~cm}^{3}$ of the sample. This gave a measure of the amount of labile heavy metal species in the water. DPASV determinations for cadmium lead, copper and zinc were carried out as previously described (Donat et al. 1994, Holak 1975). A deposition time of up to five minutes and a deposition potential of $-1.1 \mathrm{~V}$ (versus the potential of the $\mathrm{Ag} / \mathrm{AgCl}$ (saturated $\mathrm{KCl}$ ) electrode) was employed. This determination gave the accessible ASV labile amounts of trace heavy metal in the solution.

The accessible ASV labile value reveals the total amount of labile trace metal that can be measured if the water were not filtered. The accessible ASV labile amount, when compared to the soluble ASV labile amount, gives an indication of how much labile trace metal might be complexed to the larger sized constituents of the waters. Similarly, the accessible acid released labile trace metal describes the amount of complexed and non-complexed acid released labile trace metal in the water. Where the former is lower, this is an indication that the larger sized constituents of the waters can accommodate more of the particular trace metal.

\section{RESULTS AND DISCUSSION}

Tributaries of Msimbazi river contained cadmium, zinc, copper and lead at different levels (Table 1). The metals were also present at different levels of speciation. Limits of heavy metal concentration in drinking water, set by World Health Organization (WHO) are $1.5 \mathrm{ppm}$ for copper, $5.0 \mathrm{ppm}$ for zinc, $0.01 \mathrm{ppm}$ for lead and $0.003 \mathrm{ppm}$ for cadmium. The limits set by the Tanzania Bureau of Standards (TZS 573) are $3.0 \mathrm{ppm}$ for copper, $0.2 \mathrm{ppm}$ for zinc, $0.1 \mathrm{ppm}$ for lead and $0.05 \mathrm{ppm}$ for cadmium. Comparing the metal levels in river Msimbazi with these standards we observe that the copper and zinc levels at all sampling locations were within the acceptable levels for potable water. The concentration of copper varied between $0.004 \mathrm{ppm}$ and $0.048 \mathrm{ppm}$ and the level of zinc was in the range of 0.008 to $0.05 \mathrm{ppm}$.

Cadmium and lead levels in the river were higher than those acceptable for potable water. The concentration of cadmium at locations $\mathrm{A}, \mathrm{B}, \mathrm{C}, \mathrm{E}$ and $\mathrm{F}$ (Table 1) exceeded the maximum acceptable WHO level but were below the maximum acceptable Tanzanian level (TZS 573). The highest concentration of cadmium $(0.03 \mathrm{ppm})$ was found in Sinza river near Manzese area. This value is ten times higher than the WHO specification for drinking water. In the case of lead the concentrations at location B and F (i.e. at Sinza near Hanna Nasif and at Msimbazi creek) were within the WHO and Tanzania's specifications for drinking water. The levels of lead in water from location A (Sinza river at 
Manzese) and from location D (Luhanga river at Mandela road cross-section) exceeded both the WHO and Tanzania specifications for drinking water. The highest concentration of lead $(0.15 \mathrm{ppm})$ was found in Luhanga river. Other researchers (Ak'habuhaya \& Lodinius 1988, Qamara \& Othman 1996) have also reported similar high levels in river Msimbazi.

Table 1: DPASV results for cadmium, lead, copper and zinc (in $\mu \mathrm{gl}^{-1}$ ) in water samples from rivers of the Msimbazi Catchment in Dar es Salaam, Tanzania, 1998

DPASV on raw/unfiltered water samples DPASV on filtered water samples after after

\begin{tabular}{|c|c|c|c|c|c|c|}
\hline $\begin{array}{l}\text { Trace } \\
\text { metal }\end{array}$ & $\begin{array}{c}\text { Acid } \\
\text { digestion }\end{array}$ & $\begin{array}{l}\text { Acidification } \\
\text { to } \mathrm{pH}=2.8\end{array}$ & $\begin{array}{c}\text { Buffering } \\
\text { at } \mathrm{pH}= \\
4.7\end{array}$ & $\begin{array}{c}\text { Acid } \\
\text { digestion }\end{array}$ & $\begin{array}{l}\text { Acidification } \\
\text { to } \mathrm{pH}=2.8\end{array}$ & $\begin{array}{c}\text { Buffering } \\
\text { at } \mathrm{pH}= \\
4.7\end{array}$ \\
\hline \multicolumn{7}{|c|}{ From location A (Sinza river near Manzese) } \\
\hline $\begin{array}{l}\mathrm{Cd} \\
\mathrm{Cu} \\
\mathrm{Pb} \\
\mathrm{Zn}\end{array}$ & $\begin{array}{c}30 \pm 4 \\
10 \pm 3 \\
147 \pm 8 \\
48 \pm 4\end{array}$ & $\begin{array}{c}18 \pm 2 \\
7 \pm 2 \\
75 \pm 4 \\
26 \pm 2\end{array}$ & $\begin{array}{c}14 \pm 2 \\
6 \pm 1 \\
72 \pm 5 \\
22 \pm 3\end{array}$ & $\begin{array}{c}21 \pm 3 \\
9 \pm 1 \\
92 \pm 5 \\
38 \pm 2\end{array}$ & $\begin{array}{l}15 \pm 2 \\
7 \pm 1 \\
61 \pm 5 \\
28 \pm 3\end{array}$ & $\begin{array}{l}12 \pm 2 \\
5 \pm 1 \\
41 \pm 4 \\
16 \pm 3\end{array}$ \\
\hline \multicolumn{7}{|c|}{ From location B (Sinza river near Hanna Nasif) } \\
\hline $\begin{array}{l}\mathrm{Cd} \\
\mathrm{Cu} \\
\mathrm{Pb} \\
\mathrm{Zn}\end{array}$ & $\begin{array}{c}24 \pm 4 \\
9 \pm 2 \\
37 \pm 5 \\
50 \pm 5 \\
\text { From Loca }\end{array}$ & $\begin{array}{c}14 \pm 2 \\
5 \pm 3 \\
19 \pm 2 \\
16 \pm 3 \\
C \text { (Ubung }\end{array}$ & $\begin{array}{c}10 \pm 4 \\
4 \pm 1 \\
18 \pm 2 \\
29 \pm 4 \\
\text { river near }\end{array}$ & $\begin{array}{c}17 \pm 3 \\
8 \pm 2 \\
20 \pm 4 \\
38 \pm 4 \\
\text { Mabibo) }\end{array}$ & $\begin{array}{l}12 \pm 1 \\
5 \pm 1 \\
12 \pm 2 \\
23 \pm 3\end{array}$ & $\begin{array}{l}10 \pm 1 \\
4 \pm 2 \\
10 \pm 1 \\
18 \pm 3\end{array}$ \\
\hline $\begin{array}{l}\mathrm{Cd} \\
\mathrm{Cu} \\
\mathrm{Pb} \\
\mathrm{Zn}\end{array}$ & $\begin{array}{r}13 \pm 2 \\
48 \pm 4 \\
64 \pm 3 \\
34 \pm 4 \\
\text { From Loca }\end{array}$ & $\begin{array}{c}8 \pm 1 \\
31 \pm 3 \\
35 \pm 2 \\
24 \pm 1 \\
\text { on D Luhan }\end{array}$ & $\begin{array}{c}5 \pm 1 \\
27 \pm 1 \\
29 \pm 2 \\
15 \pm 2 \\
\text { river at } M\end{array}$ & $\begin{array}{c}9 \pm 3 \\
46 \pm 4 \\
41 \pm 4 \\
29 \pm 2 \\
\text { andela Roa }\end{array}$ & $\begin{array}{c}6 \pm 1 \\
34 \pm 3 \\
25 \pm 2 \\
20 \pm 5\end{array}$ & $\begin{array}{l}5 \pm 1 \\
23 \pm 2 \\
20 \pm 3 \\
13 \pm 2\end{array}$ \\
\hline $\begin{array}{l}\mathrm{Cd} \\
\mathrm{Cu} \\
\mathrm{Pb} \\
\mathrm{Zn}\end{array}$ & $\begin{array}{c}9 \pm 1 \\
22 \pm 1 \\
150 \pm 5 \\
44 \pm 2 \\
\text { From Loca }\end{array}$ & $\begin{array}{c}6 \pm 3 \\
13 \pm 1 \\
80 \pm 4 \\
27 \pm 1 \\
\mathbf{E} \text { (Msimb }\end{array}$ & $\begin{array}{l}4 \pm 1 \\
9 \pm 1 \\
70 \pm 3 \\
21 \pm 3 \\
\text { river at }\end{array}$ & $\begin{array}{c}7 \pm 3 \\
17 \pm 2 \\
72 \pm 4 \\
38 \pm 2 \\
\text { Kigogo) }\end{array}$ & $\begin{array}{l}5 \pm 1 \\
10 \pm 1 \\
44 \pm 3 \\
23 \pm 2\end{array}$ & $\begin{array}{c}4 \pm 1 \\
9 \pm 1 \\
38 \pm 2 \\
17 \pm 3\end{array}$ \\
\hline $\begin{array}{l}\mathrm{Cd} \\
\mathrm{Cu} \\
\mathrm{Pb} \\
\mathrm{Zn}\end{array}$ & $\begin{array}{l}24 \pm 2 \\
42 \pm 3 \\
86 \pm 5 \\
29 \pm 2\end{array}$ & $\begin{array}{l}14 \pm 1 \\
33 \pm 2 \\
45 \pm 3 \\
17 \pm 1\end{array}$ & $\begin{array}{l}10 \pm 1 \\
19 \pm 1 \\
41 \pm 2 \\
15 \pm 3\end{array}$ & $\begin{array}{l}17 \pm 1 \\
39 \pm 3 \\
54 \pm 2 \\
24 \pm 3\end{array}$ & $\begin{array}{l}13 \pm 1 \\
29 \pm 2 \\
36 \pm 3 \\
14 \pm 1 \\
\end{array}$ & $\begin{array}{l}10 \pm 1 \\
18 \pm 3 \\
26 \pm 2 \\
12 \pm 3\end{array}$ \\
\hline
\end{tabular}


Table 1 (Continued)

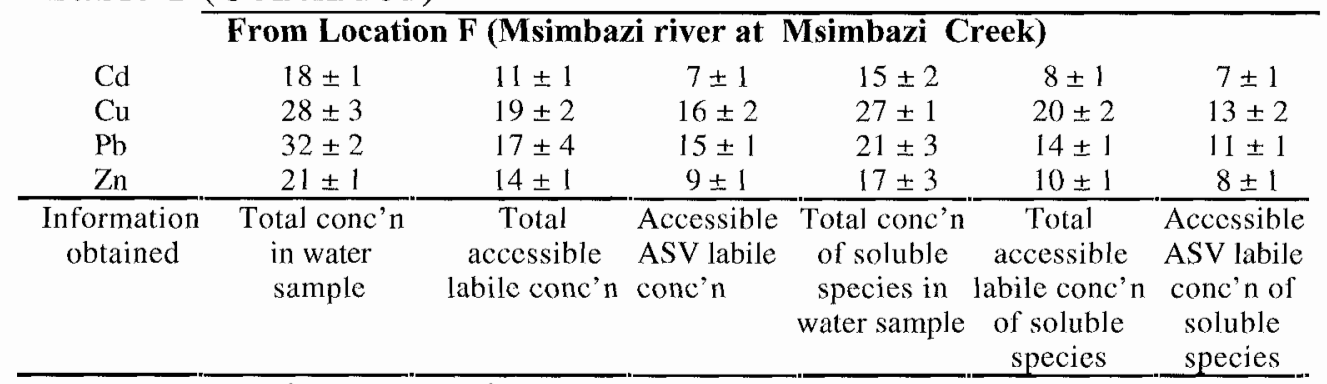

conc'n = concentration

DPASV = Differntial Pulse Anodic Stripping Voltammetry

On the average, $93.4 \%$ of copper, $82.5 \%$ of zinc, $73.7 \%$ of cadmium and $59.4 \%$ of lead in the river water existed as soluble trace metal ions (Table 2). A relatively large amount of lead (40.6\%) and only $6.6 \%$ of copper, $17.5 \%$ of zinc and $26.3 \%$ of cadmium existed as complexed to the filterable content of the waters (Table 2).

A high percentage of zinc, cadmium and copper $(61.6 \%, 61 \%$ and $65.4 \%$ respectively) and only $52.6 \%$ of lead in the raw unfiltered water existed as acid accessible labile ions (released at $\mathrm{pH} 2.8$ ). From the raw river water, 34.6 $-39 \%$ of $\mathrm{Zn}, \mathrm{Cd}$ and $\mathrm{Cu}$ and $47.6 \%$ of lead become accessible in the water by mildly acidic processes $(\sim \mathrm{pH} 4.7)$.

\begin{tabular}{|c|c|c|c|c|c|c|}
\hline \multirow[b]{2}{*}{$\begin{array}{l}\text { Trace } \\
\text { metal }\end{array}$} & \multicolumn{3}{|c|}{ Raw unfiltered river water } & \multicolumn{3}{|c|}{ Filtered river water } \\
\hline & $\begin{array}{c}\text { Percent Total } \\
\text { accessible } \\
\text { labile TMS }\end{array}$ & $\begin{array}{c}\text { Percent } \\
\text { Accessible ASV } \\
\text { labile TMS }\end{array}$ & $\begin{array}{c}\text { Percent } \\
\text { Insoluble } \\
\text { TMS } \\
\end{array}$ & \begin{tabular}{|c|} 
Percent Total \\
soluble labile \\
TMS \\
\end{tabular} & $\begin{array}{l}\text { Percent Soluble } \\
\text { ASV labile TMS }\end{array}$ & $\begin{array}{l}\text { Percent } \\
\text { soluble } \\
\text { TMS } \\
\end{array}$ \\
\hline $\begin{array}{l}\text { cadmium } \\
\text { (\% range) }\end{array}$ & $\begin{array}{c}61.0 \\
(58-67)\end{array}$ & $\begin{array}{c}42.0 \\
(38-47)\end{array}$ & $\begin{array}{c}26.3 \\
(16-31)\end{array}$ & $\begin{array}{c}48.8 \\
(38-56)\end{array}$ & $\begin{array}{c}40.8 \\
(38-47)\end{array}$ & $\begin{array}{c}73.7 \\
(70-84)\end{array}$ \\
\hline $\begin{array}{l}\text { copper } \\
\text { (\% range) }\end{array}$ & $\begin{array}{c}65.4 \\
(55-79)\end{array}$ & $\begin{array}{c}50.7 \\
(41-60)\end{array}$ & $\begin{array}{c}6.6 \\
(3-12)\end{array}$ & $\begin{array}{c}63.7 \\
(45-72)\end{array}$ & $\begin{array}{c}45.4 \\
(40-54)\end{array}$ & $\begin{array}{c}93.4 \\
(88-97)\end{array}$ \\
\hline $\begin{array}{c}\text { lead } \\
\text { (\% range) }\end{array}$ & $\begin{array}{c}52.6 \\
(51-55)\end{array}$ & $\begin{array}{c}47.4 \\
(45-49)\end{array}$ & $\begin{array}{c}40.6 \\
(34-46)\end{array}$ & $\begin{array}{c}38.0 \\
(29-44)\end{array}$ & $\begin{array}{c}29.3 \\
(24-35)\end{array}$ & $\begin{array}{c}59.4 \\
(48-66)\end{array}$ \\
\hline $\begin{array}{c}\text { zinc } \\
\text { (\% range) }\end{array}$ & $\begin{array}{c}61.6 \\
(54-71) \\
\end{array}$ & $\begin{array}{c}48.4 \\
(42-58) \\
\end{array}$ & $\begin{array}{c}17.5 \\
(13-24) \\
\end{array}$ & $\begin{array}{c}51.9 \\
(46-59) \\
\end{array}$ & $\begin{array}{c}37.6 \\
(33-42) \\
\end{array}$ & $\begin{array}{c}82.5 \\
(76-87) \\
\end{array}$ \\
\hline
\end{tabular}

ASV - Anodic Stripping Voltammetry

TMS - Trace Metal Species

Once the water is filtered we observe that, on the average, $66.2 \%$ of the cadmium, $68.6 \%$ of the lead, $63.5 \%$ of the zinc and $68.5 \%$ of the copper are 
labile in highly acidic conditions ( $\mathrm{pH} 2.8$ ). In mildly acidic conditions ( $\mathrm{pH}$ 4.7) only $48.5 \%$ of soluble $\mathrm{Cu}, 53.5 \%$ of $\mathrm{Cd}, 49.5 \%$ of $\mathrm{Pb}$ and $46.0 \%$ of $\mathrm{Zn}$ are labile as assessed by ASV. It was observed that, on the average, significant amounts of the ASV labile forms of these trace metals adhered to the filterable content of the water. Thus $30.6 \%$ of the ASV labile copper, $36.1 \%$ of the ASV labile cadmium, $20.3 \%$ of the ASV labile zinc and $57.0 \%$ of the ASV labile lead were present with the filterable contents of the water (Table 2).

The present study has shown that the pollutants in river Msimbazi and its tributaries included the heavy metals cadmium, copper, zinc and lead. These metals existed as soluble ions or were complexed to filterable contents of the water. While more than $82 \%$ of the zinc, cadmium and copper existed as soluble metal ion species, lead existed as moderately soluble ions $(<60 \%)$ and was not as labile as the other three metals. A large portion of the lead (40.6\%) was complexed to the filterable constituents of the water. Thus at least 40 percent of the lead, 26 percent of the cadmium, 17 percent of the zinc and 6 percent of the copper could be removed from the raw water just by filtration with membrane filters. More than 61 percent of the zinc, copper and cadmium found in the river water was acid-accessible trace metal species and thus probably could get directly ingested into living organisms. Only 52 percent of the lead was acid-accessible ionic species. Of the four heavy metals, cadmium and lead had very low drinking water upper concentration limits. Since very small amounts of cadmium were detected, lead was the heavy metal of concern in the river waters (found at high concentration at several points along the main river and its tributaries). Membrane filtration of the river water achieves low levels of lead rendering it safe as far as the TZS potable drinking water standards on these four heavy metals are concerned.

\section{CONCLUSION}

River Msimbazi waters were found to contain dissolved copper, zinc, cadmium and lead in various speciation forms i.e. as soluble trace metal ions, acid accessible labile species and attached to filterable contents of the waters. The four heavy metals were present at the trace level concentrations with only lead being at concentrations above both the Tanzania and WHO standards on drinking water. Cadmium concentration was above the WHO standard but within the Tanzania standard. Membrane filtration of the water rendered the water safer with all four heavy metals attaining concentrations below the limits spelled out in the Tanzania standard. The high levels of accessible labile ions of the heavy metals suggest that these metals were in ionic forms easily accessible to ingestion by animals and plants.

The present results should be considered as showing only the general behaviour and trends in cadmium, zinc, copper and lead speciation in the waters of river Msimbazi. More conclusive results on such environmental studies require continuous, systematic evaluation of the river water over 
longer periods of time especially since the contents of the river waters are constantly changing with the environmental stresses in the catchment.

\section{REFERENCES}

Ak'habuhaya J and Lodnius M 1988 Metal pollution of river Msimbazi, Tanzania. Environmental International 14: $511-514$

Anon 1978 PARC model 174A Polarographic analyzer and model 303 SMDE, operating and service manuals. Princeton Applied Research Corporation, U.S.A.

Anon 1996 Guidelines for drinking-water quality $2^{\text {nd }}$ Ed. Vol. 2: Health criteria and other supporting documents. World Health Organization, Geneva

Anon 1997 Finalized Tanzania standard specifications for naturalmineral water. Tanzania Bureau of Standards, Dar es Salaam

Batley GE 1989 Trace Element Speciation: Analytical Methods and Problems. CRC Press, Boca Raton FL, pp77-342

Batley GE and Florence TM 1976a Novel scheme for the classification of heavy metal species in natural waters. Analyt. Lett. 9:379-388

Batley GE and Florence TM 1976 b Determination of the chemical forms of dissolved cadmium, lead and copper in sea water. Mar. Chem. 4: 347

Brukland KW, Franks RP, Knauer GA and Martin JH 1979 Sampling and analytical methods for the determination of copper, zinc and nickel at nanogram per litre level in seawater. Anal. Chim. Acta 105: 233-245

Davison W 1978 Defining the electroanalytically measured species in natural water samples. J. Electroanal. Chem. 87: 395-404

Donat JR, Lao KA and Bruland KW 1994 Speciation of dissolved copper and nickel in south San-Francisco bay, a multi-method approach. Anal. Chim. Acta 284: 547-571

Figura P and McDuffie B 1980 Determination of labilities of soluble trace metal species in aqueous environmental samples by anodic stripping voltammetry, chelex column and batch methods. Anal. Chem. 52:1433-1439

Florence TM 1972 Determination of trace metals in marine samples by anodic stripping voltammetry. J. Electroanal. Chem. 35: 237-245

Florence TM 1982 The speciation of trace elements in natural waters. Talanta 29:345-364

Florence TM and Batley GE 1977 Determination of the chemical forms of trace metals in natural waters with special references to copper, lead, cadmium and zinc. Talanta 24:151-158

Holak W 1975 Determination of heavy metals in foods. Journal of the AOAC 58: $777-780$

Honeyman BD and Santschi PH 1988 Metals in the aquatic systems. Environ. Sci. Technol. 22: 862-871 
Kondoro JWA 1997 Dispersion of heavy metals along Msimbazi basin in Dar es Salaam, Tanzania. Tanz. J. Sci. 23: $1-10$

Othman OC 1986 Some alternative pulse techniques in stripping voltammetry. Ph.D. thesis, University of Dar es Salaam

Qamara J and Othman OC 1996 Cadmium, copper, lead and zinc as water pollutants in the Msimbazi catchment area - Dar es Salaam. The $5^{\text {th }}$ Annual Scientific Seminar, COSTEC, Dar es Salaam, Tanzania 